\title{
Reports
}

\section{Religious Ritual and Cooperation: Testing for a Relationship on Israeli Religious and Secular Kibbutzim $^{1}$}

\author{
RICHARD SOSIS AND BRADLEY J. RUFFLE \\ Department of Anthropology, U-2 I76, University of \\ Connecticut, Storrs, Conn. 06269-2176, U.S.A. \\ (richard.sosis@uconn.edu)/Department of Economics, \\ Ben-Gurion University, Beer Sheva, Israel 84105 \\ (bradley@bgumail.bgu.ac.il).29v o3
}

Anthropologists have long noted that one of the primary functions of religion is to promote group solidarity, and most have recognized ritual as the mechanism through which this solidarity is achieved. Guided by Durkheim (I995 [I9I2]), who was among the first to appreciate the unifying nature of religious ritual, functionalists have explored how ritual sustains the social order within a community (e.g., Douglas I966, Radcliffe-Brown 1952). They have argued that collective rituals enable the expression and reaffirmation of shared beliefs, norms, and values and are therefore essential for maintaining communal stability and group harmony. For Durkheim, collective rituals were the means by which individuals bonded with one another in the community. He claimed that the "effervescent" state of ritual performance minimized individual distinctions and emphasized the unity of the group.

Rappaport (1979, I999) extended Durkheim's analysis of ritual, primarily exploring its formal structure. He interpreted ritual's effect on group solidarity as a consequence of its communicative abilities and argued that

(C) 2003 by The Wenner-Gren Foundation for Anthropological Research. All rights reserved OOII-3204/2003/4405-0004\$I.00

I. We thank Suleiman Abubader, Candace Alcorta, K. G. Anderson, Eric Bressler, Rachel Croson, Yakov Gilboa, Mike Gurven, Joe Henrich, Todd Kaplan, Moshe Schwartz, and Robert Slonim and three anonymous reviewers for valuable comments. Our team of experimenters deserves special thanks: David Amar, Yifat Arbeli, Guy Attias, Inbar Avraham, Revital Chapani, Moti Dahan, Gil Eichholz, Sarit Fhima, Hagit Gilad, Tsahi Hasday, Avi Levy, Gidi Maor, Ronen Matmon, Hila Moshkovits, Limor Polak, Tata Pyatigorsky-Ruffle, Ze'ev Shtudiner, Amihai Toledano, Tsila Vigder-Keynan, and Limor Zahavi. We also thank the kibbutz movements for their cooperation and for agreeing to provide economic data and Shlomo Getz for supplying timely data on privatization. Funding for this project was provided by the U.S.-Israel Binational Science Foundation, the Pinhas Sapir Center for Development, the Ushi Friedman Foundation, and the University of Connecticut. [Supplementary material appears in the electronic edition of this issue on the journal's web page (http://www.journals.uchicago.edu/CA/home.html).] rituals promote trust and cooperation within communities because they indicate the accurate intentions of their performers (see also Watanabe and Smuts I999). Irons (I996a, b, c, 200I) also regards ritual performance as a means of communication but has offered an explanation of religious behavior that focuses on individual costs and benefits and considers the selective pressures that have favored religious practices. He maintains that rituals enhanced our ability to overcome the collective action problems we have likely faced throughout our evolutionary history. Irons emphasizes that the costliness of ritual actions enables them to serve as honest signals of commitment to the group because only those who are committed to the group's beliefs and goals will be willing to incur the time and energetic costs of ritual performance. In other words, individuals pay the costs of ritual performance, but by doing so they demonstrate their commitment and loyalty to the group and can thus achieve a net benefit from successful collective action.

Many others have also acknowledged and discussed the relationship between religious ritual and intragroup cohesiveness and cooperation (e.g., d'Aquili and Newberg I999, Hayden I987, Ridley I996, Sosis 2000, Steadman and Palmer 1995, Turner 1969, Wilson 2002). Although there is no consensus about how ritual promotes solidarity and cooperation, it is widely accepted that its collective nature is a critical feature. Ritual activity entails physically congregating individuals who are assumed to share ideological beliefs and social values. Indeed, anthropologists typically define ritual as an inherently social act (e.g., Radcliffe-Brown 1979, Rappaport I979). Rituals are of course also performed in solitude; however, it is collective rituals that are believed to enhance unity within the group.

Despite having achieved the status of conventional anthropological wisdom, the relationship between ritual performance and group solidarity has not been demonstrated empirically, nor has research focused on how intragroup solidarity translates into intragroup cooperation, as is expected by various researchers (e.g., Irons 200I, Rappaport I999, Sosis 2000, Sosis and Alcorta n.d., Steadman and Palmer I995). With this in mind, we designed a project aimed at examining the relationship between religious ritual and cooperation. Our research was conducted on Israeli religious and secular kibbutz members, an ideal population for evaluating this relationship. As communal societies, kibbutzim regularly face the challenge of promoting and maintaining cooperation among their members; thus the way in which group ritual affects social cohesion is pertinent to their collective existence. In addition, the clear distinction between religious and secular populations provides natural conditions for comparative analyses. Secular kibbutz members' lives are not structured by religious ritual but are 
otherwise very similar to those of religious kibbutzniks. Furthermore, the naturally occurring variation in ritual performance on religious kibbutzim, especially along gender lines, offers an opportunity to explore whether differences in individual cooperativeness can be explained by variation in ritual performance. If group ritual is the mechanism that enables religion to enhance collective action, then we should observe greater cooperation among those segments of the population that are most active in their performance of group ritual. To test this hypothesis we conducted controlled experiments on Israeli kibbutzim that involved an economic game designed to measure cooperative behavior.

\section{ISRAELI KIBBUTZIM}

The kibbutz was originally conceived as a small collective farming settlement in which members based their social and cultural lives on the collective ownership of property and wealth. Guided by the dictum "From each according to his abilities, to each according to his needs," kibbutz members received food, shelter, clothing, education, health care, and a small stipend for their work. The first kibbutz, Degania, was established in the Galilee in I909. Since then the kibbutz movement has grown to over 270 settlements located in every region of Israel. Kibbutzim range in population size from less than 50 to over 2,000 .

The kibbutz developed out of an egalitarian ideology rooted in socialist Zionism as well as the pragmatism of group living during the early colonization of Palestine by Eastern European Jews (see Near I 992). The early kibbutz members were fiercely committed to socialist and secular ideologies. Although originally agriculturally based, kibbutzim were unable to survive economically through farming alone. Over the past several decades kibbutzim have accepted the challenge and diversified their economic activities (Maron I994). Today enterprises such as tourism, health spas, and factories manufacturing the entire gamut of imaginable products provide the majority of kibbutzim's income.

The first religious kibbutz was established by the Rodges Group in I93 I and ultimately named Yavne in I94I. Since then, the Religious Kibbutz Movement (Kibbutz Dati), formally established in I935, has grown to represent over 8 , ooo members in 16 kibbutzim. The religious kibbutzim were not anticipated by the formulation of an explicit and detailed ideology (Katz I995). They integrated the secular kibbutz culture, grounded in socialist ideology, and a religious culture rooted in traditional or halachic Judaism. It was the commitment to traditional Judaism that fostered their socialist perspective. Despite their religious motivations, they modeled their communal lifestyle and economic structures after the secular kibbutzim that had preceded them (Fishman I983, I987, I992).

Religious kibbutz members practice a form of Judaism known as Modern Orthodoxy, which means that while they do not shun modernity (in contrast to the UltraOrthodox) they do adhere to halacha, or traditional Jew- ish law. Ritual plays a central role in the way religious kibbutz members organize their lives. Although a variety of requirements, such as keeping kosher and not working on the Sabbath, are imposed equally on males and females, Modern Orthodoxy is not sexually egalitarian with respect to all ritual obligations. Male ritual requirements are largely publicly oriented whereas female requirements are generally pursued privately or in the home. Indeed, of the three major requirements imposed exclusively on women, none are publicly performed (namely, the laws of family purity, such as attending a mikveh or ritual bath, separating a portion of dough when baking bread, and lighting Sabbath and holiday candles). Males, in contrast, regularly engage in a variety of collective rituals, most notably public prayer, which occurs three times daily. While females also attend synagogue occasionally, there is no religious obligation for them to pray in a group. Indeed, when women attend synagogue they sit separately from the men and are not seen by them, nor are they included in the minyan, the quorum of ten adult males needed to recite certain prayers. These gender differences in ritual practice provide an opportunity to examine directly how group ritual performance impacts cooperative behavior.

\section{HYPOTHESES}

If religious ritual impacts solidarity and cooperation as many anthropological theories suggest, then we should expect members of religious kibbutzim to exhibit higher levels of cooperation than members of secular kibbut$\mathrm{zim}$. Although there is no agreement on the details, these theories maintain that it is collective ritual that promotes solidarity and cooperation, whereas no theory proposes a similar functional role for privately performed rituals. Private rituals appear to serve a different purpose, such as communicating with oneself (e.g., Rappaport I999, Sosis 2003). Thus, we also expect that religious males will exhibit higher levels of cooperation than religious females because of their greater participation in collective ritual, especially daily prayer. Lastly, we expect the frequency of participation in collective ritual to affect an individual's cooperativeness positively. Therefore we predict that men who participate in communal prayer most frequently will exhibit the highest levels of cooperation.

\section{METHODOLOGY}

Experimental design. We developed an experimental game to test the hypothesis that collective ritual performance enhances intragroup cooperation. The game involves two members from the same kibbutz who remain anonymous to each other during and after the experiment and make their decisions independently. Each kibbutz member is told that there are roo shekels ${ }^{2}$ in an

2. A U.S. dollar equaled approximately 4 shekels at the time these experiments were conducted. Kibbutz members in our sample received monthly stipends of between 600 and 800 shekels from their respective kibbutzim. 
envelope to which both have access. Each of them independently decides how much money to withdraw from the envelope and keep. If the sum of the requests to keep money exceeds Ioo shekels, then both kibbutz members receive no money and the game is over. If the total requests are less than or equal to Ioo shekels, then each member keeps the amount he or she requested. In addition, the amount that remains in the envelope increases by $50 \%$ (i.e., is multiplied by $\mathrm{I} .5$ ) and this amount is divided in half and given to the two participants.

This game belongs to a class of experiments commonly known as common-pool-resource dilemmas (Ostrom, Gardner, and Walker I994). Two features characterize common-pool resources: nonexcludability and divisibility. Common-pool resources are publicly accessible goods that, once consumed by an individual, are no longer available for consumption. Since common-pool resources are accessible to multiple individuals who can consume the goods to depletion, their maintenance requires individual self-restraint.

Kibbutz members regularly face common-pool resource problems such as the consumption of communal food, water, electricity, and the use of communal cars, ${ }^{3}$ and thus our experimental design captures the notion of cooperation relevant to the social conditions of the kibbutz. In the experimental game, the amount of money taken out of the envelope provides a measure of a player's cooperativeness. If players do not cooperate, their total requests will exceed the amount of money available in the envelope and neither player will receive any payment. The more one cooperates by exhibiting self-restraint in one's request, the greater the level of total resources available to be divided. Our hypotheses suggest three main predictions: (I) Religious kibbutz members will take less money out of the envelope than secular kibbutz members. (2) Male religious kibbutz members will take less money out of the envelope than their female counterparts. (3) Male synagogue attendance will be negatively correlated with the amount taken out of the envelope. In addition, support for the position that collective ritual can promote cooperation will be strengthened if we find no sex differences in the amount taken out of the envelope on secular kibbutzim. In other words, if we do find a difference in the amount taken out of the envelope between religious males and females, we want to be able to attribute it to a difference in social environment and not to an inherent difference in the way males and females play the economic game.

Sample. To test our hypotheses, we constructed samples of religious kibbutzim and secular kibbutzim that were very similar along various dimensions that were assumed to affect cooperation. Seven religious kibbutzim were matched with II secular kibbutzim according to their population size, year of establishment, degree of

3. During structured interviews, many kibbutz members complained about the overconsumption of common-pool resources. Moreover, for those members who wished to see the kibbutz become more privatized, the misuse of common-pool resources was cited as the number-one reason. economic success, and degree of privatization. ${ }^{4}$ On average, religious kibbutzim are economically more successful (Fishman and Goldschmidt I990) and much less privatized (i.e., more communal) than secular kibbutzim. Thus, our sample of secular kibbutzim is not representative of the secular kibbutz movement. To match the religious kibbutzim in our sample, our secular sample consists of some of the most successful and least privatized secular kibbutzim in a movement that is otherwise economically struggling and becoming much less communal (Barkai I999, Helman I994, Leviatan, Oliver, and Quarter 1998).

A week before we conducted experiments at a kibbutz, we sent a letter of introduction to every household in the kibbutz describing the nature of the research. ${ }^{5}$ The letter informed kibbutz members that we would be calling them a day or two before our visit to invite them to participate in the research. For those who agreed to participate ( $>75 \%$ of those contacted), we arranged a specific time to meet at the participant's home. At each kibbutz visited we conducted experiments with 24-56 members, depending on the size of the kibbutz, for a total of 216 observations on religious kibbutzim and 342 observations on secular kibbutzim. All data were collected between February and May 2000.

Data collection. All of our data collection procedures were refined during extensive pilot studies conducted at Ben-Gurion University and three secular kibbutzim not in our sample. To facilitate data collection and to reduce the chances that participants who completed the experiment could contact others who might be scheduled to participate, 20 Ben-Gurion University graduate and undergraduate students were employed so that multiple experiments could be conducted simultaneously. Typically, about I 2 researchers visited a kibbutz.

Experimenters were paired before their arrival at a kibbutz. Paired experimenters maintained contact with each other via cellular phone throughout the stay on the kibbutz. Upon arrival at the kibbutz, the two experimenters searched for the homes of their first participants. Before entering, they spoke with each other by phone to report that they had found the participants' residences. Then they entered the houses of their respective participants simultaneously so that paired participants would begin the experiment at the same time.

Upon entering a home, the experimenter introduced him- or herself and requested a quiet place where they could sit undisturbed for the next 30 minutes. Once seated, the experimenter conveyed some preliminary details concerning the experiment (e.g., that the participants' identity and decisions would remain anonymous).

4. These data were obtained from an annual survey on privatization
conducted by Shlomo Getz. We measured privatization as the num-
ber of practices (2 I total) that were no longer communal. For ex-
ample: Are kibbutz members required to pay for their vacations
abroad? Do the members have to pay for meals in the communal
dining hall? Is the ownership of private cars permitted? Does the
kibbutz have a differential pay scale?
5. Prior to sending the letters, we obtained permission to conduct
the research from the secretary (head) of each kibbutz in our sample. 
The participant was then given the instruction sheet and told to read the instructions carefully. Then the experimenter read the instructions aloud. To ensure complete comprehension of the game, two random examples were performed. In each example, a pair of numbers was randomly drawn from a bag containing numerical values between $\mathrm{o}$ and roo. The numbers were meant to be the amounts chosen by two hypothetical participants in the experimental game. Thus, for instance, if the numbers Io and 70 were drawn from the bag, the participant was shown that the first player would receive 25 shekels and the second player would receive 85 shekels, since the 20 shekels left over would increase to 30 shekels and be split between them.

After any clarifying questions had been answered, a decision was elicited regarding the amount the participant wished to remove from the envelope. Following this decision, each participant was asked to indicate the amount he or she believed the other would remove from the envelope in order to help identify the motivation behind the participant's claim. The experimenter of the participant who decided first then telephoned the other experimenter to report that a decision had been reached. The experimenter did not convey the amount of the decision in this conversation in order to avoid any reaction or facial expression on the part of the second experimenter that could influence the second participant's decision. Further, immediately revealing the participant's decision might have made him or her suspicious that the decision was being conveyed to the other participant, who would then use this information to make a decision. After the second participant reached a decision, the other experimenter was phoned and the decisions were exchanged. Each experimenter then conveyed to the participant the other's decision, the amount remaining in the envelope, and the amount that he or she would receive after the amount leftover in the envelope (if any) was increased by $50 \%$ and divided in two.

After the experiment, structured interviews were conducted to collect data on a variety of demographic and behavioral variables relevant to the research hypotheses. At the conclusion of the interview, participants were paid their earnings from the experiment in cash.

\section{RESULTS}

On average, religious males $(n=$ I08) removed 29.9 shekels from the envelope, religious females $(n=$ I08) removed 33.7 shekels, secular males $(n=170)$ removed 30.I shekels, and secular females $(n=\mathrm{I} 72)$ removed 30.5 shekels. In order to compare these subpopulations in our sample we conducted Tobit regression analyses and controlled for a host of variables that we thought might impact cooperativeness. ${ }^{6}$ Potential demographic and kibbutz-level predictors are described in table I. Although other research in progress (Ruffle and Sosis n.d.) has

6. Tobit regression coefficients need to be transformed in order to interpret them as marginal effects like ordinary least squares estimates. The results reported here are robust; all of our qualitative findings are identical with ordinary least squares specifications. shown that several kibbutz-level variables are significant predictors of the amount of money withdrawn from the envelope, in the sample employed here there is too little variance along these dimensions and therefore none of the kibbutz-level variables (kibbutz age, membership size, economic strength, and degree of privatization) tested in Tobit analyses are significant. ${ }^{7}$

Table 2 presents the results of separate Tobit regressions performed on the religious and secular kibbutz samples, where the amount removed from the envelope is the dependent variable. As hypothesized, within the religious kibbutz sample sex is a significant predictor of the amount of money removed from the envelope. Controlling for a variety of explanatory variables, religious males on average claim 5.8 shekels less than females. Secular male and female kibbutz members do not remove significantly different amounts from the envelope, and therefore the significant sex difference observed in the religious kibbutzim is unlikely to be a consequence of inherent differences in the way males and females respond in this experimental game.

In both the religious and secular kibbutz samples, the amount a participant expects his or her partner to remove from the envelope displays a significant curvilinear relationship with actual claims from the envelope, as indicated by the significant "predict" and "predictsquared" variables. The other significant variables differ across samples. In the religious kibbutz sample, the fraction of one's life spent on the kibbutz is a significant predictor of claims. This variable was shown to be important in previous analyses (of data collected on another sample of kibbutzim) that explored the impact of kibbutz socialization on cooperative decisions (Ruffle and Sosis 2002). These previous analyses showed that individuals born on the kibbutz took out more than those who had moved to the kibbutz, and the more time one had lived on the kibbutz the more one removed from the envelope (controlling for age). Those who move to a kibbutz are typically motivated by a strong ideological commitment to socialism and communal life. The results suggest that individuals who believe passionately enough in the values of communal life to move to a kibbutz initially cooperate more than those who have spent more of their lives on the kibbutz. In the secular kibbutz sample, employment location is a strong predictor of cooperative decisions. Members who work outside the kibbutz claim less than those who work on the kibbutz. Individuals who work outside the kibbutz are typically professionals and earn salaries well above the Israeli average, yet as kibbutz members they are required to contribute these high salaries to the kibbutz. Their choice to remain on the kibbutz rather than join mainstream Israeli society may therefore reflect their commitment to the kibbutz values of community and cooperation. Another predictor in the secular kibbutz sample, albeit marginally signif-

7. We also found no significant effects by experimenter, including whether the experimenter dressed religiously, and no evidence that the numerical examples used during the explanatory phase of the experiment had any impact on participants' decisions. 
TABLE I

Independent Variables Used in Tobit Regression Analyses

\begin{tabular}{|c|c|c|c|c|}
\hline \multirow{2}{*}{$\begin{array}{l}\text { Independent } \\
\text { Variable }\end{array}$} & \multicolumn{2}{|c|}{ Religious Kibbutzim } & \multicolumn{2}{|c|}{ Secular Kibbutzim } \\
\hline & Mean & Standard Deviation & Mean & Standard Deviation \\
\hline $\operatorname{Sex}^{\mathrm{a}}$ & 0.50 & 0.50 & 0.50 & 0.50 \\
\hline Age & 49.96 & I 8.07 & $47 \cdot 32$ & I 5.86 \\
\hline $\begin{array}{l}\text { Fraction of life } \\
\text { spent on } \\
\text { kibbutz }\end{array}$ & 0.66 & 0.26 & 0.67 & 0.29 \\
\hline $\begin{array}{l}\text { Years of } \\
\text { education }\end{array}$ & I 3.89 & 3.03 & I 4.06 & 2.64 \\
\hline Marital status ${ }^{\mathrm{b}}$ & 0.86 & 0.34 & 0.67 & 0.47 \\
\hline $\begin{array}{l}\text { Number of } \\
\text { households on } \\
\text { kibbutz with } \\
\text { kin }\end{array}$ & 2.73 & 2.97 & 2.39 & 2.37 \\
\hline $\begin{array}{l}\text { Number of } \\
\text { meals eaten } \\
\text { per week in } \\
\text { communal } \\
\text { hall }\end{array}$ & 9.00 & 5.78 & $8.5 \mathrm{I}$ & 5.49 \\
\hline$\underset{\text { location }^{c}}{\text { Employment }}$ & $0.2 \mathrm{I}$ & $0.4 \mathrm{I}$ & 0.23 & 0.42 \\
\hline $\begin{array}{l}\text { Kibbutz age } \\
\text { (years) }\end{array}$ & 53.09 & 7.65 & 62.92 & $\mathrm{I} 4.75$ \\
\hline Population size & 658.26 & $209 \cdot 30$ & 652.78 & I85.I2 \\
\hline $\begin{array}{l}\text { Economic } \\
\text { strength }^{\mathrm{d}}\end{array}$ & $2.2 \mathrm{I}$ & 0.74 & I. 84 & 0.86 \\
\hline $\begin{array}{l}\text { Number of pri- } \\
\text { vatization } \\
\text { changes } \\
\text { adopted by } \\
\text { kibbutz }\end{array}$ & 2.10 & I. 56 & 2.I I & $\mathrm{I} .42$ \\
\hline $\begin{array}{l}\text { Synagogue } \\
\text { attendance }\end{array}$ & 4.59 & 1.20 & - & - \\
\hline $\begin{array}{l}\text { Amount pre- } \\
\text { dicted partner } \\
\text { would claim } \\
\text { (shekels) }\end{array}$ & 39.76 & I 4.25 & $4 \mathrm{I} . \mathrm{I} 5$ & 17.62 \\
\hline
\end{tabular}

NOTE: Religious kibbutzim, $n=2$ I6; secular kibbutzim, $n=342$. Variables without explicit coding schemes were coded directly as the value of the variable.

${ }^{\mathrm{a} O}$, female; I, male.

${ }^{\mathrm{b}} \mathrm{O}$, not currently married; I, married.

'O, on kibbutz; I, outside of kibbutz.

${ }^{\mathrm{d}} \mathrm{I}$, very strong; 2 , strong; 3 , fair; 4 , weak; 5 , very weak.

${ }^{\mathrm{e}} \mathrm{I}$, never; 2, seldom; 3, holidays only; 4, Sabbath and holidays; 5, several times per week; 6, daily.

icant, is the frequency with which members eat in the communal dining hall, which is negatively correlated with the amount removed from the envelope.

Data on synagogue attendance were collected during the postexperiment interviews. Participants from religious kibbutzim were asked to indicate their synagogue attendance on a six-point scale with the following categories: daily (6), several times per week (5), Sabbath and holidays (4), holidays only (3), seldom (2), and never (I). The average male response was 5.5 and the average female response was 3.7. This difference is significant $\mid t=$ I 6.23; d.f. $=203 ; p<.000 \mathrm{I})$. The histograms in figure I indicate that male synagogue attendance is negatively correlated with the amount claimed from the envelope (Pearson $r=-$.18; $n=$ I02; $p=.036$ ), whereas female synagogue attendance is unrelated to claims (Pearson $r$ $=.05 ; n=$ I02; $p=.626$ ). Controlling for variables shown to be significant in the religious sample (table 2), the Tobit regression in table 3 shows that religious males who attend synagogue daily remove significantly less money from the envelope than religious females, whereas there is no significant difference in the amounts claimed by religious females and religious males who do not attend synagogue daily.

The regression specifications in table 4 , which include all kibbutz members (religious and secular), control for the significant predictors found in the above analyses (table 2). Column I provides a controlled comparison of the cooperative behavior of the four subpopulations. Three of the four subpopulations are represented with 
TABLE 2

Tobit Regression Models of the Amount Removed from the Envelope

\begin{tabular}{|c|c|c|}
\hline & Religious Kibbutzim & Secular Kibbutzim \\
\hline Independent Variable & $\begin{array}{l}\text { Parameter Estimate } \\
\text { (Standard Error) }\end{array}$ & $\begin{array}{c}\text { Parameter Estimate } \\
\text { (Standard Error) }\end{array}$ \\
\hline Intercept & $3.43(\mathrm{I} 0.22)$ & $-6.85(7.8 \mathrm{I})$ \\
\hline Sex & $-5.80(2.53)^{b}$ & $2.40(1.93)$ \\
\hline Predict & $\mathrm{I} .32(0.34)^{\mathrm{c}}$ & I.2 I $(0.14)^{c}$ \\
\hline Predict-squared & $-0.012(0.005)^{b}$ & $-0.009(0.002)^{c}$ \\
\hline $\begin{array}{l}\text { Fraction of life spent } \\
\text { on kibbutz }\end{array}$ & I I.93 $(4.99)^{\mathrm{b}}$ & $-0.94(3.8 \mathrm{I})$ \\
\hline Age & $-0.12(0.07)$ & 0.09 (0.07) \\
\hline Employment location & $-0.75(3.29)$ & $-7.36(2.20)^{\mathrm{c}}$ \\
\hline Marital status & $3.14(3.77)$ & $\mathrm{I} .69(2.2 \mathrm{I})$ \\
\hline Education & $-0.34(0.42)$ & O.I I (0.38) \\
\hline $\begin{array}{l}\text { Number of kin } \\
\text { households }\end{array}$ & $0.03(0.4 \mathrm{I})$ & $0.49(0.44)$ \\
\hline Number of meals & $-0.06(0.23)$ & $-0.32(0.18)^{a}$ \\
\hline
\end{tabular}

dummy variables, with religious males as the base category. The results in column I show that, controlling for significant predictors, religious males take out less than religious females (similar to the results in table 2), secular males, and secular females. The results in column 2 indicate that, controlling for significant predictors, religious kibbutzniks on average take out less than secular kibbutz members. Column 3 shows that this is largely attributable to males who attend synagogue regularly: when male synagogue attendance is included in the regression the religious dummy variable is no longer significant, whereas the male daily synagogue attendance interaction term is highly significant (similar to the results in table 3 ). Column 4 includes dummy variables for secular males and females, while the religious male population is divided between those who attend synagogue daily and those who do not; religious females are the base category. The results indicate that religious females claim less than secular males $(p=.055)$, but they do not claim significantly different amounts from secular females.

\section{DISCUSSION AND CONCLUSIONS}

The analyses presented here provide support for the thesis that collective ritual can promote cooperation. Controlling for a host of significant predictors, religious males on average remove significantly less from the envelope than religious females, secular females, and secular males. There is no significant difference in claims between secular males and females, and therefore the sex differences observed on the religious kibbutzim are probably not a result of inherent differences in the way males and females play this experimental game but a consequence of differing social environments. In Modern
Orthodoxy men are expected to pray communally (with at least ten men) three times daily, whereas there is no obligation for women to pray communally, and therefore attending synagogue is not a collective ritual for females. Our data indicate that collective ritual has a significant impact on cooperative decisions: male synagogue attendance is negatively correlated with claims (see fig. I, tables 3 and 4). In addition, the difference in claims between religious males and females is largely attributable to variation in male synagogue attendance. Religious males who attend synagogue daily remove significantly less than religious females, whereas there is no significant difference in the amounts claimed by religious females and religious males who do not attend synagogue daily.

On secular kibbutzim, there are no collective rituals (secular or religious) that occur as consistently and frequently as the thrice-daily prayer of religious male kibbutz members. Data collected on the frequency with which participants attend communal events indicate that secular kibbutz members on average attend only about two communal events per month, with no evidence of any difference between the sexes $(t=$ I.65; d.f. $=258 ; p=.23)$. Interestingly, although attending communal meals has no effect on the cooperative decisions of religious kibbutzniks, it appears to have a marginal effect on cooperativeness among secular kibbutzniks, which may suggest that communal meals are serving as a collective ritual in an environment devoid of religious rituals.

If collective ritual performance positively impacts cooperation, it is curious that in the religious kibbutz sample the longer one spends on the kibbutz the less cooperative one becomes. However, a closer look at the 
data reveals that females are largely responsible for this effect. Tobit regressions indicate that the fraction of one's life spent on the kibbutz is a significant predictor of the amount claimed among the female religious kibbutz population $(\beta=\mathrm{II} .04 ; \sigma=5.59 ; n=\mathrm{I0} 8 ; p=.048)$ but not among the male religious kibbutz population $(\beta$ $=\mathrm{I} 3.46 ; \sigma=8.38 ; n=\mathrm{I07} ; p=$.I I). It is understandable that among those who join the kibbutz enthusiasm for cooperation wanes as one's initial idealism gives way to the actual challenges of living communally; however, collective ritual appears to counteract this effect. Among males who attend synagogue daily the fraction of one's life spent on the kibbutz has no relation to amounts claimed (Pearson $r=$. II $n=68 ; p=.357$ ), whereas among males who do not attend synagogue daily there is a positive and marginally significant correlation between amount claimed and fraction of one's life spent on the kibbutz (Pearson $r=.30 ; n=33 ; p=.089$ ).

It may be argued that males who regularly participate in collective ritual take out less from the envelope not because they are more cooperative than their fellow kibbutz members but because they are risk-averse. In other words, these men claim more modest sums of money because they fear that the combined requests will exceed roo shekels, resulting in no payment. If males who regularly engage in collective ritual are taking out less because of a fear that the joint requests will
TABLE 3

Tobit Regression Model of the Amount

Removed from the Envelope by Members of

Religious Kibbutzim

\begin{tabular}{lc}
\hline Independent Variable & $\begin{array}{c}\text { Parameter Estimate } \\
\text { (Standard Error) }\end{array}$ \\
\hline $\begin{array}{l}\text { Intercept } \\
\text { Religious*male*synagogue } \\
\text { daily }\end{array}$ & $-0.97(5.69)$ \\
$\begin{array}{l}\text { Religious*male*synagogue } \\
\text { not daily }\end{array}$ & $-6.84(2.54)^{\mathrm{b}}$ \\
$\begin{array}{l}\text { Predict } \\
\text { Predict-squared }\end{array}$ & $-3.24(3.35)$ \\
$\begin{array}{l}\text { Fraction of life spent on } \\
\text { kibbutz }\end{array}$ & I.I4 $(0.29)^{\mathrm{b}}$ \\
\hline
\end{tabular}

NOTE: $n=\mathrm{I} 98$, adjusted $R^{2}=0.2 \mathrm{I} 4$.

${ }^{\mathrm{a}} p<.05$.

${ }^{\mathrm{b}} p<$.OI.

exceed Ioo shekels, then ritual participation should be positively correlated with predictions of the amount that partners will remove from the envelope. However, the amount that religious males predict their partners will remove is negatively correlated with synagogue attendance (Pearson $r=-.242 ; n=98 ; p=.016)$, in-

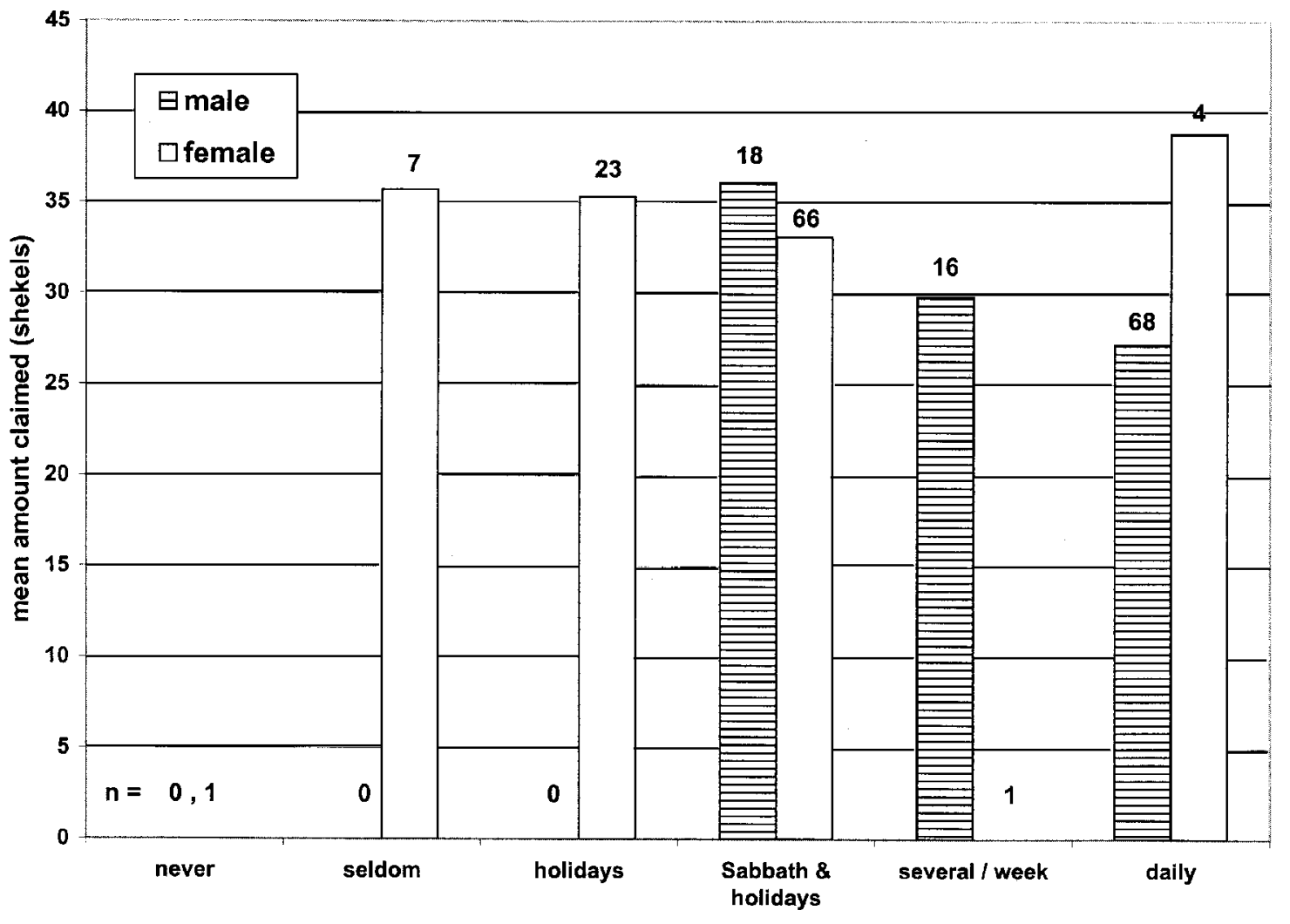

FIG. I. Mean amount claimed by synagogue attendance for religious males and females. 
TABLE 4 Tobit Regression Models of the Amount Removed from the Envelope by Members of All Kibbutzim

\begin{tabular}{|c|c|c|c|c|}
\hline & I & 2 & 3 & 4 \\
\hline Independent Variable & $\begin{array}{l}\text { Parameter Estimate } \\
\text { (Standard Error) }\end{array}$ & $\begin{array}{l}\text { Parameter Estimate } \\
\text { (Standard Error) }\end{array}$ & $\begin{array}{l}\text { Parameter Estimate } \\
\text { (Standard Error) }\end{array}$ & $\begin{array}{l}\text { Parameter Estimate } \\
\text { (Standard Error) }\end{array}$ \\
\hline Intercept & $-7.12(4.18)$ & $3.19(3.2 \mathrm{I})$ & $3.52(3.2 \mathrm{I})$ & $-3.23(4.15)$ \\
\hline Predict & I.I4 $(0.12 \mathrm{I})^{c}$ & I.I4 $(0.12 \mathrm{I})^{c}$ & $\begin{array}{l}\text { I.I } 3(. \mathrm{I} 2 \mathrm{I})^{\mathrm{c}} \\
\mathrm{I}\end{array}$ & I.I $2(. \mathrm{I} 2 \mathrm{I})^{\mathrm{c}}$ \\
\hline Predict-squared & $-0.008(0.002)^{c}$ & $-0.008(0.002)^{c}$ & $-0.008(0.002)^{c}$ & $-0.008(0.002)^{c}$ \\
\hline Religious & - & $-7.24(3.66)^{\mathrm{b}}$ & $-5.92(3.78)$ & - \\
\hline $\begin{array}{l}\text { Fraction of life } \\
\text { spent on } \\
\text { kibbutz } \\
\text { religious }\end{array}$ & $8.25(4.42)^{\mathrm{a}}$ & $7.27(4.42)^{\mathrm{a}}$ & $8.99(4.5 \mathrm{I})^{\mathrm{b}}$ & $9.79(4.56)^{\mathrm{b}}$ \\
\hline $\begin{array}{l}\text { Employment } \\
\text { location* } \\
\text { secular }\end{array}$ & $-6.9 \mathrm{I}(2.15)^{\mathrm{c}}$ & $-6.87(\mathrm{I} .98)^{\mathrm{c}}$ & $-6.86(2.15)^{c}$ & $-6.74(2.39)^{\mathrm{c}}$ \\
\hline $\begin{array}{l}\text { Number of } \\
\text { meals* } \\
\text { secular }\end{array}$ & $-0.29(0.16)^{\mathrm{a}}$ & -0.26 (0.18) & $-0.27(0.17)$ & $-0.24(0.18)$ \\
\hline $\begin{array}{l}\text { Religious* } \\
\text { female }\end{array}$ & $4.92(2.25)^{\mathrm{b}}$ & - & - & - \\
\hline Secular*male & I I. $77(4.08)^{\mathrm{c}}$ & - & - & $7.65(3.99)^{a}$ \\
\hline Secular*female & $9.48(3.99)$ & - & - & $4.78(3.9 \mathrm{I})$ \\
\hline $\begin{array}{l}\text { Religious* } \\
\text { male*syna- } \\
\text { gogue daily }\end{array}$ & $\begin{array}{c}9.40 \\
-\end{array}$ & - & $-6.56(2.54)^{\mathrm{c}}$ & $-6.43(2.56)^{b}$ \\
\hline $\begin{array}{l}\text { Religious* } \\
\text { male*syna- } \\
\text { gogue not } \\
\text { daily }\end{array}$ & - & - & $-3.59(3.36)$ & $-3.53(3.47)$ \\
\hline
\end{tabular}

Note: I, $n=497$, adjusted $R^{2}=0.256 ; 2, n=497$, adjusted $R^{2}=0.252 ; 3, n=486$, adjusted $R^{2}=0.258 ; 4, n=486$, adjusted $R^{2}=$ 0.263 .

${ }^{\mathrm{a}} p<$. IO.

${ }^{\mathrm{b}} p<.05$.

${ }^{\mathrm{c}} p<$.OI.

dicating that religious males are motivated not by fear but by their belief that others will behave cooperatively.

Life on the kibbutz is undergoing rapid social and ideological change, change not embraced by all kibbutz members (Ben-Rafael I 997). It is possible that religious females are more disappointed with the direction of the kibbutz, which may explain why they are less cooperative toward their fellow members than their male counterparts, and that males who are dissatisfied with changes in the kibbutz are not only less cooperative than others but less likely to attend communal functions such as public prayer. To evaluate this possibility we asked participants during postexperiment interviews to rate their level of satisfaction with recent changes on their kibbutz on a five-point scale. Contrary to the claim that religious females and religious males who do not attend synagogue daily are disaffected subpopulations within the kibbutz, we found no difference in levels of satisfaction between males who attend synagogue daily and those who do not $(t=2.00 ;$ d.f. $=55$; $p=.294)$, and religious females are more satisfied with the changes on their kibbutzim than males who attend synagogue daily $(t=\mathrm{I} .98$; d.f. $=\mathrm{I} 3 \mathrm{I} ; p=.0$ I 2$)$. Indeed, Tobit analyses indicate that satisfaction with changes on the kibbutz does not predict amounts claimed from the envelope $(\beta=-0.19 ; \sigma=$ I.I $3 ; n=2$ I0; $p=.866)$.

Additional data collected during postexperiment interviews further support our finding that those who engage regularly in collective ritual perceive others to be more cooperative and therefore are themselves more cooperative. Participants were asked to rate the level of cooperation on their kibbutz on a five-point scale with "very high" equaling five points and "very low" equaling one point. Multiple linear regression analyses indicate that none of the variables in table I are significant predictors of cooperation ratings for religious females, including synagogue attendance (linear model: $\beta=$ o.IO; $F=0.94$; d.f. $=$ I; $p=.334$ ). For religious males, only synagogue attendance and employment location are correlated with cooperation ratings $\left(r^{2}=. \mathrm{IO}\right.$; $F=5.08$; d.f. $=2 ; p=.008$; synagogue attendance: $\beta$ $=0.20 ; p=.06$; employment location: $\beta=-0.47 ; p=$ $.02)$. In other words, consistent with our expectations, males who attend synagogue more regularly perceive a greater level of cooperation and solidarity on the kibbutz than those who attend less frequently, whereas synagogue attendance has no impact on females' perception of cooperation on the kibbutz. Of course, these 
data, as well as the experimental game data, are incapable of distinguishing the causal direction of this relationship. We suggest that collective ritual participation influences beliefs (perceived levels of cooperation) and behavior (cooperative decisions) and therefore assume, as numerous theorists following Durkheim have claimed, that ritual participation enhances the social bonds that connect its participants. It is also possible, though we find it unlikely, that those who perceive greater levels of cooperation on the kibbutz are more likely to participate regularly in collective ritual.

Our results raise a number of questions that need to be addressed in future work. First, how do secular kibbutz members maintain solidarity and cooperation? Although many of the secular kibbutzim are experiencing a genuine social and economic crisis (Ben-Rafael i997, Leviatan, Oliver, and Quarter I998), as was noted above, the secular kibbutzim in our sample are relatively successful and stable. What mechanisms other than collective ritual contribute to the observed solidarity and cooperation on secular kibbutzim? Second, what is the mechanism through which ritual impacts cooperativeness? Some work has begun to examine this question, especially evaluating Irons's theory of ritual as a commitment mechanism (Sosis 2000, Sosis and Bressler 2003). Third, how do collective rituals vary in their ability to impact group solidarity? What are the critical features of collective ritual that promote cooperation? Future research in the anthropology of religion must explore these questions. There is an abundance of theories that attempt to explain the relationship between religion and group solidarity; our immediate problem is not a lack of ideas but a paucity of data that could be used to evaluate these theories systematically. This is where our future efforts must lie.

\section{References Cited}

B A R K A I, H. I999. Franz Oppenheimer's transformation law and the recent trend towards privatization in the kibbutz. Hebrew University of Jerusalem Working Paper \# $\mathrm{I}$.

BEN-RAFAEL, E. I997. Crisis and transformation: The kibbutz at century's end. Albany: State University of New York Press.

D'AQUILI, E., AND A. NEWBERG. I999. The mystical mind. Minneapolis: Fortress Press.

Douglas, M. I966. Purity and danger. New York: Praeger. DURKHEIM, E. I995 (I9I2). The elementary forms of religious life. New York: Free Press.

F I SHMAN, A. I983. "The religious kibbutz: Religion, nationalism, and socialism in a communal framework," in The sociology of the kibbutz. Edited by E. Krausz, pp. I I5-23. New Brunswick: Transaction Press.

- I987. Religion and communal life in an evolutionaryfunctional perspective: The orthodox kibbutzim. Society for Comparative Study of Society and History 29:763-86.
- I992. Judaism and modernization on the religious kibbutz. Cambridge: Cambridge University Press.

FISHMAN, A., AND Y. GOLDSCHMIDT. I990. The orthodox kibbutzim and economic success. Journal for the Scientific Study of Religion 29:505-I I.

GREENE, W. I993. 5th edition. Econometric analysis. Upper Saddle River, N.J.: Prentice-Hall.

HAYDEN, B. I987. Alliances and ritual ecstasy: Human responses to resource stress. Journal for the Scientific Study of Religion 26:8I-9I.

HELMAN, A. I994. Privatization and the Israeli kibbutz experience. Journal of Rural Cooperation 22:19-32.

I RON S, W. I996a. In our own self-image: The evolution of morality, deception, and religion. Skeptic 4:50-6I.

. I996b. "Morality as an evolved adaptation," in Investigating the biological foundations of morality. Edited by J. P. Hurd, pp. I-34. Lewiston: Edwin Mellon Press.

- I996c. "Morality, religion, and human nature," in Religion and science: History, method, and dialogue. Edited by W. M. Richardson and W. Wildman. New York: Routledge.

. 200I. "Religion as a hard-to-fake sign of commitment," in The evolution of commitment. Edited by Randolph Nesse, pp. 292-309. New York: Russell Sage Foundation.

к A TZ, Y. I995. The religious kibbutz movement and its credo, I935-I948. Middle Eastern Studies 31:253-80.

leviatan, U., h. Oliver, and J. Quarter. I998. Crisis in the Israeli kibbutz. New York: Greenwood Publishing Group.

MARON, S. I994. Recent developments in the kibbutz: An overview. Journal of Rural Cooperation 22:5-17.

NE A R, H. I992. The kibbutz movement: A history. Vol. I. New York: Oxford University Press.

OSTROM, E., R. GARDNER, AND J. WALKER. I994. Rules, games, and common-pool resources. Ann Arbor: University of Michigan Press.

RADCLIFFE-BROWN, A. I952. Structure and function in primitive society. London: Cohen and West.

- 1979. "Taboo," in Reader in comparative religion, 4th edition. Edited by W. Lessa and E. Vogt, pp. 46-56. New York: Harper and Row.

R A P P A P O R T, R. I979. "The obvious aspects of ritual," in Ecology, meaning, and religion. Edited by R. Rappaport, pp. I73-22 I. Richmond, Calif.: North Atlantic Books.

. I999. Ritual and religion in the making of humanity. Cambridge: Cambridge University Press.

RIDLEY, M. I996. The origins of virtue. New York: Penguin Books.

RUFFLE, B., AND R. SOSIS. 2002. Just how cooperative are kibbutz members? Field experiments on Israeli kibbutzim and in Israeli cities. Paper presented to the annual meeting of the American Economic Association, January.

. n.d. How does privatizing a collective enterprise affect intra-group cooperation? MS.

S OSIS, R. 2000. Religion and intra-group cooperation: Preliminary results of a comparative analysis of utopian communities. Cross-Cultural Research 34:70-87.

- 2003. Why aren't we all Hutterites? Costly signaling theory and religious behavior. Human Nature I4.

Sosis, R., AND C. ALCORTA. n.d. Signaling, solidarity, and the sacred: The evolution of religious behavior. Evolutionary Anthropology. In press.

SOSIS, R., AND E. BRESSLER. 2003. Cooperation and commune longevity: A test of the costly signaling theory of religion. Cross-Cultural Research 37:2 I I-39.

STEADMAN, L., AND C. PALMER. I995. Religion as an identifiable traditional behavior subject to natural selection. Journal of Social and Evolutionary Systems 18:149-64.

TURNER, V. I969. The ritual process. Chicago: Aldine.

W A T ANABE, J., AND B. SMUTS. I999. Explaining religion without explaining it away: Trust, truth, and the evolution of cooperation in Roy A. Rappaport's "The Obvious Aspects of 
Ritual." American Anthropologist ior:98-I I2.

WIL S ON, D. 2002. Darwin's cathedral: Evolution, religion, and the nature of society. Chicago: University of Chicago Press.

\section{Sunk-Cost Effects and Vulnerability to Collapse in Ancient Societies ${ }^{1}$}

MARCO A. JANSSEN, TIMOTHY A. KOHLER, AND MARTEN SCHEFFER Center for the Study of Institutions, Population, and Environmental Change, Indiana University, $408 \mathrm{~N}$. Indiana Ave., Bloomington, Ind. 47408-3799, U.S.A. (maajanss@indiana.edu)/Department of Anthropology, Washington State University, P.O. Box 6449Io, Pullman, Wash.99I64-49Io, U.S.A. (tako@wsu.edu)/ Department of Aquatic Ecology and Water Quality Management, Wageningen University, P.O. Box 8080, NL-6700 DD Wageningen, The Netherlands

(marten.scheffer@aqec.wkao.wau.nl).26 vo3

Judging by the variety of explanations proffered in the literature, societies apparently collapse for a variety of reasons. In an influential review, Tainter (I988:39-90) reports that published explanations for the famous collapses of the Classic Maya, the western Roman Empire, and many other less famous episodes such as the demise of the Chimu of Peru or the Chacoan system in the U.S. Southwest tend to fall into I I major categories, with resource depletion or deterioration being one of the most commonly adduced causes (see, for example, Hodell, Curtis, and Brenner I995, Weiss and Bradley 200I). Another common explanation is insufficient response to circumstances, or "failure to adapt."

Tainter (I988:50, emphasis added) rejects both such explanations. Resource-degradation explanations raise the question why

societies sit by and watch the encroaching weakness without taking corrective actions. ... As it becomes apparent to the members or administrators of a complex society that a resource base is deteriorating, it

(C) 2003 by The Wenner-Gren Foundation for Anthropological Research. All rights reserved oOI I-3204/2003/4405-0005\$I.00

I. We thank Marty Anderies, Jared Diamond, Katja Hogendoorn, Garry Peterson, Henry Wright, and four anonymous reviewers for their useful suggestions. We began this collaboration following acquaintances made at a Santa Fe Institute-sponsored Long-Term Human Dynamics Working Group meeting. Janssen acknowledges support from NSF SBR952 I 9 I 8 and Kohler from NSF BCS-OI I 998 I and many useful conversations about the northern Southwest with W. D. Lipe and M. D. Varien. [Supplementary material appears in the electronic edition of this issue on the journal's web page (http: //www.journals.uchicago.edu/CA/home.html).] seems most reasonable to assume that some rational steps are taken towards a resolution. . . . If a society cannot deal with resource depletion (which all societies are to some extent designed to do) then the truly interesting questions revolve around the society, not the resource. What structural, political, or economic factors in a society prevented an appropriate response?

As to the possibility that societies fail because they are inherently fragile or static or incapable of shifting directions, Tainter (I988:54-6I, 89) considers this not so much an explanation as something that, if true in particular cases, must be explained.

\section{SUNK-COST EFFECTS: INDIVIDUALS AND GROUPS}

In this report we seek to unite these two explanations in a model that suggests why and under what conditions societies faced with resource degradation might "fail to adapt." We are not peddling a new universal theory for societal collapse; we do hope to insert into the anthropological conversation on collapse a mechanism-little noticed to date-making some societies more vulnerable to collapse under certain conditions. Our model, which we illustrate with a simple mathematical characterization, is based on a well-documented systematic deviation from rational decision making known as the "sunk-cost effect" (Arkes and Ayton I999). Rational-choice theory tells us that one's choice between options should be influenced not by prior investment but only by the expected future costs and benefits of those options. Of course, prior investment may affect the knowledge and experience of the decision maker, but such effects can be included in the rational-choice theory explanation of decision making. Numerous studies (Arkes and Blumer I985, Arkes and Ayton I999, Teger I980) nevertheless demonstrate that humans do consider prior investment in deciding what course of action to take.

Most sunk-cost research is focused on individual decision making. Explanations of observed escalation of commitment are self-justification, not admitting that past decisions were incorrect, and framing effects (whether the problem is framed in positive or negative outcomes) (Staw I997). One might expect that such irrational behavior could be corrected in groups. Groups, however, are actually more prone than individuals to succumb to the sunk-cost effect (Whyte r993). Nor is this effect limited to Western society; conformist (or frequency-dependent) transmission is a leading candidate for explaining behavior (including self-sacrificial cooperation in large groups) that is otherwise difficult to account for (Boyd and Richerson I985:204-40). Indeed, a typical goal for political decisions in small-scale societies is consensus (Boehm I996). Once members of a group reach consensus, the easiest way to maintain it is to stay committed to the group's decision (Janis I972). Thus, even when the group is faced with negative results, members may not suggest abandoning an earlier course of action, since this might break the existing unanimity. 